\title{
Ballistic Performance of 21 Layered Hybrid Composites
}

\author{
Cenk YANEN ${ }^{1}$, Murat Yavuz SOLMAZ ${ }^{2}$
}

\begin{abstract}
This paper experimentally investigates usability of multilayered hybrid composite as personal body armor material which is an important parameter in ballistic fabric energy. This study four hybrid composites material with different thickness and number of layers have been produced by using 3 different types of fabric. Then ballistic tests have been performed by using Beretta gun and 9 mm FMJ bullet according to the National Institute of Justice 0101.06 standards. In the ballistic tests, the speed of bullets and the depth of penetration occurring on the test samples have been measured and the damages have been assessed. The results show that unidirectional hybrid composites show a superior ballistic performance as compared to the other hybrid composites.
\end{abstract}

Keywords - Hybrid composite, Ballistic performance, Armor material.

\section{INTRODUCTION}

$\mathrm{C}$ URRENTLY high-strength polymer fabrics are widely used for protective systems due to their mechanical properties and impact resistance [1]. High performance polymer fibers such as aramid fibers, carbon fibers and glass fibers have remarkable properties such as lightness, flexibility, high Young's modulus and good impact resistance, which make them attractive candidates for the manufacturing of modern protective equipment [2].

The effect of hybridization of glass-carbon fabric was reported by Pandya et al. [3]. They studied the ballistic impact behavior of symmetric hybrid composites made using plain weave E-glass fabric and $8 \mathrm{H}$ satin weaved $\mathrm{T} 300$ carbon fabric with epoxy resin. It was found that the placing of E-glass layers in the exterior and carbon layers in the interior provides higher ballistic limit velocity than placing carbon layers in the exterior and E-glass layers in the interior.

Nayak et al. [4] investigated the ballistic impact responses of plain woven aramid/epoxy composites with thicknesses from 10 to $25 \mathrm{~mm}$. They concluded that the ballistic limit shows linear change with the laminate thicknesses. Furthermore, delamination fiber breakage and pull out constituted the mechanisms of penetration and major energy absorption. Based on Zhang et al. [5], a bi-linear relationship was found between the ballistic limit velocity and sample

Cenk YANEN ${ }^{1}$ is with Firat University, Elazig, 23119 TURKEY. He is now with the Mechancial Engineering Department (corresponding author's phone: +904242370000-5322; e-mail: cyanen@ firat.edu.tr).

Murat Yavuz SOLMAZ ${ }^{2}$ is with Firat University, Elazig, 23119 TURKEY. $\mathrm{He}$ is now with the Mechancial Engineering Department (e-mail: mysolmaz@firat.edu.tr). thickness. The increase in thickness of UHMWPE composites demonstrated a two-stage penetration process; shear plugging during the initial penetration followed by the formation of a transition plane and bulging of a separated rear panel [6]. Wambua et al. [7] reported increase of ballistic impact velocity (V50) for increasing composite thickness. V50 refers to the ballistic impact velocity for which there is a $50 \%$ chance of penetration and $50 \%$ of non-perforation of the composites.

The effect of hybrid composites was studied experimentally by Randjbaran et al. [8] to investigate the effects of stacking sequence layers of hybrid composite materials on ballistic energy absorption [9].

In a ballistic back face signature test, the NIJ standard for personal protection [10] requires that a projectile to be stopped and the penetration depth of depression (indentation) into a clay witness (backing the armor) should not exceed 1.73 in. $(\sim 44 \mathrm{~mm})$. Deeper penetrations are associated with lethal trauma inflicted to the wearer. Therefore, the smaller the indentation, the better the armor ballistic performance should be.

One of the most well-known polymeric fibers for protective systems is aramid fiber with the commercial name Kevlar [11]. Fabrics made with this aramid fiber have high strength, high modulus and good tenacity, which are desirable properties for ballistic applications; however, they are relatively expensive and the design of protective equipment with these fabrics should include studies to reduce the amount of required fabric layers without compromising the effectiveness of the armor.

The aim of this study is to produce layered hybrid composites for personal body armor and to ensure high ballistic resistance and lightness. In this study, 21 layered hybrid composite test samples have been produced and ballistic tests have been performed according to NIJ 0101.06 standard and the results have been investigated. The ballistic tests have been performed by using Beretta Gun and $9 \mathrm{~mm}$ FMJ bullet from $5 \mathrm{~m}$ distance. In this study we have focused on if the test samples have been succesful according to mentioned NIJ 0101.06 standard. Materials and experimental procedures are described in Section 2. Results and discussion are presented in Section 3, followed by conclusions in Section 4.

\section{METHODS}

\section{A. Materials}

In this study four hybrid layered composite test samples have been produced. Four configurations were tested: (i) [Glass $\left(45^{\circ}\right) 7 /$ Aramid (plain)7 /Carbon $\left.\left(45^{\circ}\right) 7\right]$, (ii) [Glass $\left(0^{\circ}\right) 7$ /Aramid (plain)7 /Carbon $\left.\left(0^{\circ}\right) 7\right]$, (iii) [Glass(plain)7 /Aramid (plain)7 /Carbon(plain)7] and (iiii) [Glass(twill)7 /Aramid 
(plain)7 /Carbon(twill)7]. For all configurations, plain-woven aramid was used. . The properties of these fabrics are given in Table I.

TABLE I

THE FIBER FABRIC USED IN SAMPLE PRODUCTION

\begin{tabular}{|l|l|c|}
\hline Fabric Name & Fabric Type & Density $\left[\mathrm{gr} / \mathrm{m}^{2}\right]$ \\
\hline Carbon Fiber & Unidirectional $0^{\circ}$ & 300 \\
\hline Carbon Fiber & Unidirectional 45 & 400 \\
\hline Glass Fiber & Unidirectional $0^{\circ}$ & 300 \\
\hline Glass Fiber & Unidirectional 45 & 460 \\
\hline Aramid Fiber & Plain Woven & 410 \\
\hline Carbon Fiber & Plain Woven & 200 \\
\hline Carbon Fiber & Twill Woven & 245 \\
\hline Glass Fiber & Plain Woven & 200 \\
\hline Glass Fiber & Twill Woven & 282 \\
\hline
\end{tabular}

\section{B. Fabrication of Composite Laminates and Sample} Configuration

Hybrid laminated composites of $200 \mathrm{~mm}$ x $200 \mathrm{~mm}$ size was used for the ballistic testing. The hand-lay-up method was used to fabricate laminated hybrid composites. Aramid, Carbon and Glass fabrics were hand laid-up with the epoxy matrix by mixing epoxy resin (Hexion MGS L326) and hardener (Hexion H265) in the ratio of 4:1. Two thick mild steel plates were used as a mold $(200 \mathrm{~mm} \times 200 \mathrm{~mm})$ in the fabrication process [12]. The composites were cured by applying compression pressure using at 20 bar pressure. The test samples have been cured by increasing the temperature gradually from $20 \mathrm{C}^{\circ}$ to $110 \mathrm{C}^{\circ}$ in 4 hours. The schematic of test sample is given in Fig. 1 [13].

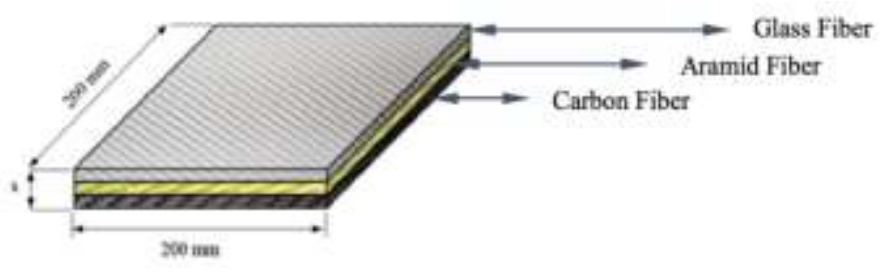

Fig 1. The schematic of the structure of [Glass/Aramid/Carbon] layered hybrid polyester resin matrix

The properties of layered hybrid composite produced in Firat University Mechanical Laboratory are given in Table II.

TABLE II

PROPERTIES OF LAYERED HYBRID COMPOSITE

\begin{tabular}{|l|l|c|c|c|}
\hline Name & Material & $\begin{array}{l}\text { Number } \\
\text { of layers }\end{array}$ & $\begin{array}{l}\text { Weight } \\
{[\mathrm{gr}]}\end{array}$ & $\begin{array}{l}\text { Density } \\
{\left[\mathrm{gr} / \mathrm{cm}^{3}\right]}\end{array}$ \\
\hline B5 & $\begin{array}{l}\text { [Glass }\left(45^{\circ}\right) / \text { Aramid } \\
\left.\text { (plain)/Carbon }\left(45^{\circ}\right)\right]\end{array}$ & 21 & 554 & 1.54 \\
\hline B6 & $\begin{array}{l}\text { [Glass }\left(0^{\circ}\right) / \text { Aramid } \\
\left.\text { (plain)/Carbon }\left(0^{\circ}\right)\right]\end{array}$ & 21 & 468 & 1.63 \\
\hline B7 & $\begin{array}{l}\text { [Glass (plain)/Aramid } \\
\text { (plain)/Carbon (plain)] }\end{array}$ & 21 & 372 & 1.55 \\
\hline B8 & $\begin{array}{l}\text { [Glass (twill)/Aramid } \\
\text { (plain)/Carbon (twill)] }\end{array}$ & 21 & 432 & 1.54 \\
\hline
\end{tabular}


Four shots were performed to 21 layered plates. Test results photos of B5 sample is given in the Fig. 3. Bullet velocity and kinetic energy values that calculated with these velocities is defined by chronograph between center point of target and weapon given in Table III.

TABLE III

BALLISTIC TEST RESULT OF B5 SAMPLE

\begin{tabular}{|l|l|l|l|l|}
\hline \multicolumn{5}{|c|}{ Sample Sequence: [Glass $\left(45^{\circ}\right)_{7} /$ Aramid (plain $)_{7} /$ Carbon $\left.\left(45^{\circ}\right)_{7}\right]$} \\
\hline $\begin{array}{l}\text { Shot } \\
\text { Number }\end{array}$ & $\begin{array}{l}\text { Bullet } \\
\text { Velocity } \\
(\mathrm{m} / \mathrm{s})\end{array}$ & $\begin{array}{l}\text { Kinetic } \\
\text { Energy } \\
(\mathrm{Nm})\end{array}$ & $\begin{array}{l}\text { Depth of } \\
\text { Penetration } \\
(\mathrm{mm})\end{array}$ & Evaluation \\
\hline 1 & 389 & 606,00 & 8,00 & No Perforation \\
\hline 2 & 279 & 312,28 & 5,70 & No Perforation \\
\hline 3 & 428 & 729,40 & 10,60 & No Perforation \\
\hline 4 & 394 & 621,28 & 9,35 & No Perforation \\
\hline & & & & \\
\hline Average & 372 & 567,24 & 8,41 & \\
\hline
\end{tabular}

None of shots to first of 21 layered sample caused perforation and sample verified as successful. Average of 4 shot to sample B5 is $372 \mathrm{~m} / \mathrm{s}$ and corresponding depth of penetration value is $8,41 \mathrm{~mm}$. This sample verified as successful according to NIJ level II-A. In this sample carbon fiber fabric functioned as support plate cause fiber damage at directions $\pm 45^{\circ}$ because of it is $45^{\circ}$ and hard structured.

Second sample that ballistic test of it performed is [Glass $\left(0^{\circ}\right) 7 /$ Aramid (plain)7 /Carbon $\left.\left(0^{\circ}\right) 7\right]$ sequenced B6. Ballistic test results of B6 sample is given in Fig. 4. Bullet velocity, kinetic energy and their assessment is given in Table IV.

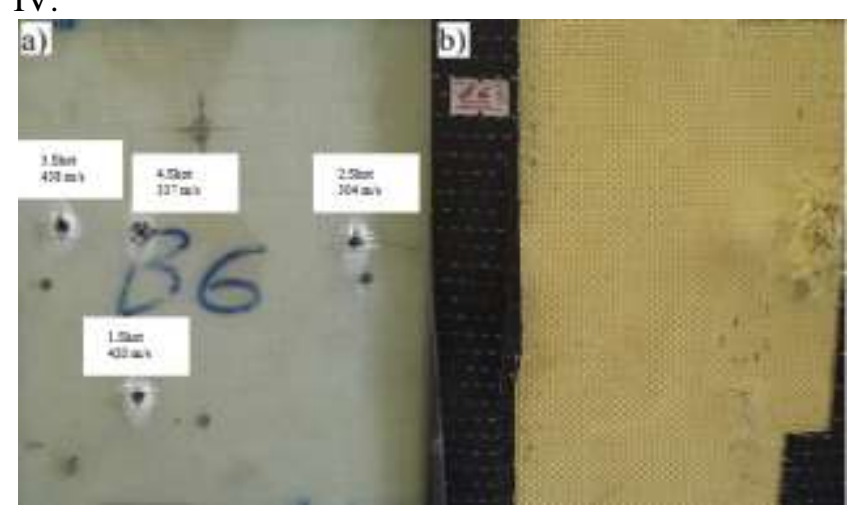

Fig 4. [Glass $\left(0^{\circ}\right) 7 /$ Aramid (plain) $7 /$ Carbon $\left.\left(0^{\circ}\right) 7\right]$ test sample a) front view $b$ ) rear view

TABLE IV

BALLISTIC TEST RESULT OF B6 SAMPLE

\begin{tabular}{|l|l|l|l|l|}
\hline \multicolumn{5}{|c|}{ Sample Sequence: [Glass $\left(0^{\circ}\right)_{7} /$ Aramid (plain $)_{7} /$ Carbon $\left.\left(0^{\circ}\right)_{7}\right]$} \\
\hline $\begin{array}{l}\text { Shot } \\
\text { Number }\end{array}$ & $\begin{array}{l}\text { Bullet } \\
\text { Velocity } \\
(\mathrm{m} / \mathrm{s})\end{array}$ & $\begin{array}{l}\text { Kinetic } \\
\text { Energy } \\
(\mathrm{Nm})\end{array}$ & $\begin{array}{l}\text { Depth of } \\
\text { Penetration } \\
(\mathrm{mm})\end{array}$ & Evaluation \\
\hline 1 & 420 & 705,65 & 7,30 & No Perforation \\
\hline 2 & 304 & 369,39 & 5,80 & No Perforation \\
\hline 3 & 337 & 455,39 & 6,80 & No Perforation \\
\hline 4 & 438 & 768,44 & - & Perforation \\
\hline & & & & \\
\hline Average & 354 & 510,14 & 6,63 & \\
\hline
\end{tabular}

Fourth shot have $438 \mathrm{~m} / \mathrm{s}$ one of 4 shots performed to sample B6 caused perforation. At back face carbon fiber plate with effect of crash rupture happened. Except shot number 4 other shots average depth of penetration value is $6,63 \mathrm{~mm}$ corresponding to average $354 \mathrm{~m} / \mathrm{s}$ bullet velocity.
Shot number 4 perforation happened, fiber plates and leave the system by rupturing.

Ballistic test results of [Glass(plain)7/Aramid(plain)7/ Carbon(plain)7] sequenced B7 sample is given in Fig. 5. Bullet velocity, kinetic energy and their assessment is given in Table V.

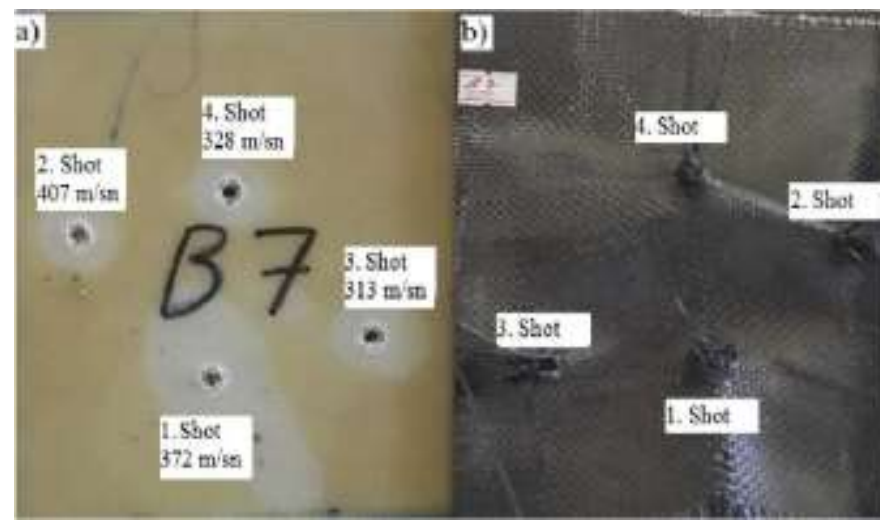

Fig 5. [Glass(plain) $)_{7} /$ Aramid (plain) ${ }_{7} /$ Carbon(plain) $)_{7}$ test sample a) front view b) rear view

TABLE V

BALLISTIC TEST RESULT OF B7 SAMPLE

\begin{tabular}{|c|c|c|c|c|}
\hline $\begin{array}{l}\text { Shot } \\
\text { Number }\end{array}$ & $\begin{array}{l}\text { Bullet } \\
\text { Velocity } \\
(\mathrm{m} / \mathrm{s})\end{array}$ & $\begin{array}{l}\text { Kinetic } \\
\text { Energy } \\
(\mathrm{Nm})\end{array}$ & $\begin{array}{l}\text { Depth of } \\
\text { Penetration } \\
(\mathrm{mm})\end{array}$ & Evaluation \\
\hline 1 & 372 & 554,01 & - & Perforation \\
\hline 2 & 407 & 663,29 & - & Perforation \\
\hline 3 & 313 & 391,19 & - & Perforation \\
\hline 4 & 328 & 429,44 & - & Perforation \\
\hline Average & 355 & 509,48 & - & \\
\hline
\end{tabular}

The bullet speeds of shots to B7 test sample have been between $313 \mathrm{~m} / \mathrm{s}$ and $407 \mathrm{~m} / \mathrm{s}$. All of these shots have resulted with perforation and the samples have been unsuccessful.

Test results photos of B5 sample is given in the Fig. 6 . Bullet velocity and kinetic energy values that calculated with these velocities is defined by chronograph between center point of target and weapon given in Table VI.

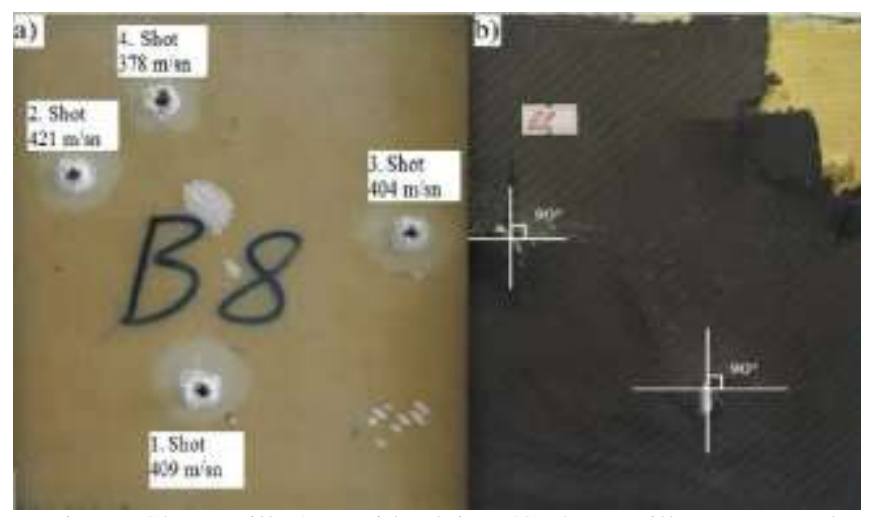

Fig 6. [Glass(twill) $)_{7} /$ Aramid (plain $)_{7} /$ Carbon(twill $\left.)_{7}\right]$ test sample a) front view $b$ ) rear view 
TABLE VI

BALLISTIC TEST RESULT OF B8 SAMPLE

\begin{tabular}{|l|l|l|l|l|}
\hline \multicolumn{5}{|c|}{ Sample Sequence: [Glass(twill $)_{7} /$ Aramid (plain $)_{7} /$ Carbon(twill $\left.)_{7}\right]$} \\
\hline $\begin{array}{l}\text { Shot } \\
\text { Number }\end{array}$ & $\begin{array}{l}\text { Bullet } \\
\text { Velocity } \\
(\mathrm{m} / \mathrm{s})\end{array}$ & $\begin{array}{l}\text { Kinetic } \\
\text { Energy } \\
(\mathrm{Nm})\end{array}$ & $\begin{array}{l}\text { Depth of } \\
\text { Penetration } \\
(\mathrm{mm})\end{array}$ & Evaluation \\
\hline 1 & 409 & 668,26 & - & Perforation \\
\hline 2 & 421 & 707,70 & - & Perforation \\
\hline 3 & 404 & 652,41 & 10,0 & No Perforation \\
\hline 4 & 378 & 572,31 & 7,5 & No Perforation \\
\hline & & & & \\
\hline Average & 391 & 612,36 & 8,75 & \\
\hline
\end{tabular}

Perforation has been occurred in the Shot-1 and Shot-2 of 4 shots to B8 test sample with speed of $409 \mathrm{~m} / \mathrm{s}$ and $421 \mathrm{~m} / \mathrm{s}$ respectively. In the shots no puncture has occurred due to the carbon fiber fabric in the rear of the test sample is in twill type, fiber damage has been occurred in both horizontal and vertical directions. Carbon fiber plate has ruptured with Shot2. In the Shot-1 damage has been occurred in fiber fabric due to twill weaving type and also, perforation has been observed. The average bullet speed has been $391 \mathrm{~m} / \mathrm{s}$ and the average depth of penetration has been $8.75 \mathrm{~mm}$ of all shots accept Shot-1 and Shot-2 in which perforation has been occurred.

\section{CONCLUSIONS}

In this study, test samples have been produced to investigate the usability of layered hybrid composites as personal armor material. Ballistic tests of these samples have been performed with the reference of NIJ.0101-06 standard and the results of the tests have been investigated. The structural configuration of the test sample and the evaluations of the ballistic test results are given in Table VII.

TABLE VII

THE BALLISTIC TEST RESULTS

\begin{tabular}{|l|l|l|l|l|}
\hline Name & Material & $\begin{array}{l}\text { Number } \\
\text { of layers }\end{array}$ & $\begin{array}{l}\text { Mass } \\
{[\mathrm{gr}]}\end{array}$ & Evaluation \\
\hline B5 & $\begin{array}{l}{\left[\text { Glass }\left(45^{\circ}\right) / \text { Aramid }\right.} \\
\left.\text { (plain)/Carbon }\left(45^{\circ}\right)\right]\end{array}$ & 21 & 554 & II-A \\
\hline B6 & $\begin{array}{l}{\left[\text { Glass }\left(0^{\circ}\right) / \text { Aramid }\right.} \\
\left.\text { (plain)/Carbon }\left(0^{\circ}\right)\right]\end{array}$ & 21 & 468 & Puncture \\
\hline B7 & $\begin{array}{l}{[\text { Glass (plain)/Aramid }} \\
\text { (plain)/Carbon (plain) }]\end{array}$ & 21 & 372 & Puncture \\
\hline B8 & $\begin{array}{l}{[\text { Glass (twill)/Aramid }} \\
\text { (plain)/Carbon (twill) }]\end{array}$ & 21 & 432 & Puncture \\
\hline
\end{tabular}

In the ballistic tests conducted with the B5 sample, the value of BFS was observed to be $5.70 \mathrm{~mm}$ at $279 \mathrm{~m} / \mathrm{s}$ and $10.60 \mathrm{~mm}$ at $427 \mathrm{~m} / \mathrm{s}$, which is the lowest projectile speed. The increase in the amount of depression versus the increase of 417.12 joules in the projectile kinetic energy has been 4.90 $\mathrm{mm}$.

The first three shots with speeds of $304 \mathrm{~m} / \mathrm{s}, 337 \mathrm{~m} / \mathrm{s}$ and $420 \mathrm{~m} / \mathrm{s}$ made to the B6 sample resulted in no damage to the material and the fourth shot at $438 \mathrm{~m} / \mathrm{s}$ resulted in perforation and the sample failed.

All shots having speeds of $313 \mathrm{~m} / \mathrm{sec}, 328 \mathrm{~m} / \mathrm{sec}, 372 \mathrm{~m} /$ sec and $407 \mathrm{~m} / \mathrm{sec}$ made to the B7 sample were perforated and the sample failed.

The first two shots with speeds of $409 \mathrm{~m} / \mathrm{s}$ and $421 \mathrm{~m} / \mathrm{s}$ made to the B8 sample resulted in perforation. No damage was found on the sample in the other shots having speeds of $404 \mathrm{~m}$ / $\mathrm{s}$ and $378 \mathrm{~m} \mathrm{/} \mathrm{s.} \mathrm{However,} \mathrm{this} \mathrm{ball} \mathrm{has} \mathrm{been} \mathrm{considered}$ unsuccessful in terms of ballistic protection due to the perforation of the first two throws.

B5 with [Carbon $\left(45^{\circ}\right) 7 /$ Aramid(plain)7/ Glass $\left(45^{\circ}\right) 7$ ] lineup has been observed to be the only successful test samples in the ballistic tests.

By considering the results of all test, $45^{\circ}$ unidirectional fabrics have been determined to have better ballistic resistance from $0^{\circ}$ unidirectional fabrics.

When woven fabrics are examined among themselves, it has been determined that the ballistic strength of fabrics with twill weaving structure is better than fabrics with plain weaving structure.

When the unidirectional fabrics are examined, it has been determined that ballistic use is more suitable for fabrics having a $0^{\circ}$ angle depending on the structural characteristics of the unidirectional fabrics having an angle of $45^{\circ}$.

In all experiments, it was determined that the unidirectional fabrics with an angle of $45^{\circ}$ were more successful than the ones with plain fabric type.

The damage types have been investigated after the ballistic tests and damage of fiber and separation of layers have been observed to be the most common damage types.

Behind the protection property, another important factor in the design of armor material is lightness property. The successful test samples of the ballistic tests in this study can be recommended to study to reach an optimum weight and thickness with better ballistic resistance by reducing the number of layers for new armors.

\section{REFERENCES}

[1] A. Tabiei, G. Nilakantan, Ballistic impact of dry woven fabric composites: a review, Appl. Mech. Rev. 61 (1) (2008) 010801.

[2] J.G. Carrillo, R.A. Gamboa, E.A. Flores-Johnson, P.I. Gonzalez-Chi, Ballistic performance of thermoplastic composite laminates made from aramid woven fabric and polypropylene matrix: Polymer Testing 31 (2012) $512-519$

[3] L.M. Nunes, S. Paciornik, J.R.M. d'Almeida, Evaluation of the damaged area of glass-fiber-reinforced epoxy-matrix composite materials submitted to ballistic impacts, Compos. Sci. Technol. 64 (2004) 945954.

[4] N. Nayak, A. Banerjee, A.L. Dutta, Ballistic performance of laminated composites gainst military impactors: experimental and numerical studies, vol. 2, in: DYMAT 2009 - 9th Int. Conf. Mech. Phys. Behav. Mater under Dyn. Load., 2009, pp. 1761-1766.

[5] D. Zhang, Y. Sun, L. Chen, S. Zhang, N. Pan, Influence of fabric structure and thickness on the ballistic impact behavior of Ultrahigh molecular weight polyethylene composite laminate, Mater. Des. 54 (2014) 315-322.

[6] L.H. Nguyen, S. Ryan, S.J. Cimpoeru, A.P. Mouritz, A.C. Orifici, The effect of target thickness on the ballistic performance of ultra high molecular weight polyethylene composite, Int. J. Impact Eng (2014).

[7] P. Wambua, B. Vangrimde, S. Lomov, I. Verpoest, The response of natural fibre composites to ballistic impact by fragment simulating projectiles, Compos. Struct. 77 (2007) 232-240.

[8] E.Randjbaran, R. Zahari, N.A.Abdul Jalil,D.L.AbangAbdul Majid,Hybrid composite laminates reinforced with kevlar/carbon/glass woven fabrics for ballistic impact testing, Sci.World J. 2014 (2014) 413753.

[9] R. Yahaya, S.M. Sapuan, M. Jawaid, Z. Leman, E.S. Zainudin, Measurement of ballistiv impact properties of woven kenaf-aramid hybrid composites. Measurement 7(2016) 335-343

[10] NIJ Standard 0101.06, Ballistic Resistance of Personal Body Armor, US Depart. of Justice, July 2008. 
[11] H.H. Yang, Kevlar Aramid Fiber, John Wiley \& Sons, 1993.

[12] Yanen, C., Solmaz, M.Y., "Production and experimental investigation of ballistic performance of laminated hybrid composites", Fourth International Conference on Advances in Mechanical and Automation Engineering - MAE 2016, pp. 32-36.

[13] Yanen, C., Solmaz, M.Y., "Investigation of ballistic performance of laminated hybrid composites", 22nd International Conference on Engineering Mechanics Location: Svratka, Czech Republıc May 09-12, 2016, pp. 590-593.

[14] Yanen, C., "Tabakalı Hibrit Kompozitlerin Bireysel Zırh Malzemesi Olarak Kullanılabilirliğinin Araştırılması" 2016, Yüksek Lisans Tezi, Fırat Üniversitesi, Fen Bilimleri Enstitüsü, Elazığ. 